\title{
ANALISIS LABA AKUNTANSI DAN LABA TUNAI TERHADAP DIVIDEN KAS PADA PERUSAHAAN FARMASI TAHUN 2013 -2017
}

\author{
APRIL LESTARI 1; RAKHMAWATI OKTAVIANNA2 \\ Prodi Akuntansi S1, Fakultas Ekonomi, Universitas Pamulang \\ Email: r.oktavianna21@gmail.com
}

\begin{abstract}
This study aims to examine the relationship between accounting earning and cash earning with cash dividend in the pharmaceutical sub-sector companies listed on the Indonesian Stock Exchange during the periode of 2013 to 2017. This study uses secondary data, namely financial report sata from manufacturing companies that are accessed from the official websitre of the Indonesia Stock Exchange. The selection of samples in this study used a purposive sampling technique, namely the technique of collecting samples with certain considerations or sample selection techniques with certain criteria aimed at getting a representative sample according to the specified criteria. The data analysis model used is multiple regression analysis. In addition to using data analysis in this study is an analysismethod with EViews statistical tools version 9. Based on the result of the study show that partially accounting earnings affect cash dividends while cash earnings do not affect cash dividends but simultaneously accounting earnings and cash earnings have a significant effect on cash dividends.
\end{abstract}

Keywords: accounting earning; cash earning; cash dividend

\section{PENDAHULUAN}

Pertumbuhan ekonomi di Indonesia kian tahun semakin berkembang. Perkembangan inilah yang memacu para pengusahan untuk mengelola perusahaannya di Indonesia. Tiap tahunnya banyak perusahaan baru didirikan di Indonesia. Pada kebanyakan perusahaan yang merupakan organisasi bisnis umumnya memiliki tiga tujuan utama yaitu kelanjutan hidup perusahaan (going concern), laba dalam jangka panjang (profit), dan perluasan usaha (expansion). Hal yang harus diperhatikan dalam pengelolaan perusahaan yaitu mengenai pengelolaan keuangan untuk kelangsungan operasional perusahaan berkaitan dengan sumber dana dan penggunaanya, semakin efisien penggunaan dan pengelolaan maka semakin baik kondisi keuangan perusahaan.

Laba merangkum dampak keuangan aktivitas operasi usaha. Tujuan utama laporan laba rugi adalah menjelaskan bagaimana laba dihitung dengan komponen 
penting yang disajikan dalam pos terpisah (John; 2010).

Perusahaan untuk dapat terus tumbuh dan berkembang dalam menjalankan bisnis atau usahanya membutuhkan dana yang cukup besar. Sehubungan dengan hal ini, perusahaan senantiasa dihadapkan pada permasalahan mengenai bagaimana memperoleh dana, bagaimana menggunakannya dan mengembalikan dana yang diperoleh tersebut dengan suatu tingkat pengembalian yang dapat memuaskan pihak pemberi dana. Salah satu alternatif memperoleh pendanaan adalah melalui penerbitan dan penjualan saham di Bursa Efek Indonesia, dimana para investor dapat menginvestasikan dananya dengan cara membeli saham. Investasi saham dapat dilakukan dengan dua cara, yaitu dengan membeli saham dari emiten (perusahaan yang menerbitkan saham) atau membeli dari pemegang saham lama. Dari sisi emiten kebijakan dividen sangat penting bagi mereka, apakah sebagai keuntungan perusahaan akan lebih banyak digunakan untuk membayar dividen dibanding saldo laba atau sebaliknya. Dalam penetapan kebijaksanaan mengenai pembagian dividen, faktor yang menjadi perhatian manajemen adalah besarnya laba yang dihasilkan perusahaan. Ada dua ukuran kinerja akuntansi perusahaan yaitu laba akuntansi dan total arus kas. (Bustanul Arifin ; 2012).

Dividen merupakan salah satu daya tarik investor untuk menanamkan dananya di pasar modal. Investor lebih menyukai dividen yang berupa kas dibanding dengan capital gain. Dividen juga merupakan salah satu alat yang dapat digunakan untuk mengurangi konflik keagenan antara pemegang saham mayoritas dan pemegang saham minoritas karena pembayaran dividen menunjukkan bawha pemegang saham mayoritas tidak melakukan tindakan ekspropriasi terhadap pemegang saham minoritas. Namun pembagian dividen kas tidak hanya sekedar berdasarkan laba akuntansi (laba bersih) yang tertera dilaporan keuangan tetapi juga perlu mempertimbangkan laba tunai (nilai kas bersih) yang dimiliki oleh perusahaan. Perusahaan harus mempunyai persediaan kas yang cukup untuk membayar dividen kas. Perusahaan yang mempunyai laba tapi tidak mempunyai dana kas yang cukup tidak dapat membagikan dividen kas dikarenakan akan mengganggu aktivitas normal perusahaan

Dari penjelasan dan penelitian terdahulu tersebut, maka tujuan dari penelitian ini adalah untuk menganalisis laba akuntansi dan laba tunai terhadap dividen kas pada perusahaan farmasi yang masuk dalam BEI tahun 2013 sampai dengan tahun 2017.

\section{LANDASAN TEORI DAN HIPOTESIS}

\section{Teori Agensi dan Teori Signal}

Dalam mengimplementasikan tujuan perusahaan yaitu memaksimalkan kekayaan para pemegang saham, masalah keagenan dapat saja terjadi. Masalah keagenan (agency problem) merupakan masalah yang timbul akibat konflik kepentingan antara manajer (agen pemegang saham) dengan pemegang saham karena adanya pemisahan tugas manajemen perusahaan dengan para pemegang saham (Keown at al, 2008). Agen adalah orang yang diberi kekuasaan untuk bertindak atas nama yang lain, yang dikenal sebagai prinsipal. Dalam mengatur 
perusahaan, pemegang saham adalah prinsipal, karena mereka adalah pemilik nyata dari perusahaan. Sedangkan dewan direksi, CEO, para eksekutif perusahaan maupun manajer profesional dengan kekuasaaan pengambilan keputusan adalah agen (perantara) dari pemegang saham.

Isyarat atau signal adalah suatu tindakan yang diambil perusahaan untuk memberi petunjuk bagi investor tentang bagaimana manajemen memandang prospek perusahaan. Sinyal ini berupa informasi mengenai apa yang sudah dilakukan oleh manajemen untuk merealisasikan keinginan pemilik. Informasi yang dikeluarkan oleh perusahaan merupakan hal yang penting, karena pengaruhnya terhadap keputusan investasi pihak diluar perusahaan. Informasi tersebut penting bagi investor dan pelaku bisnis karena informasi pada hakekatnya menyajikan keterangan, catatan atau gambaran, baik untuk keadaan masa lalu, saat ini maupun masa yang akan datang bagi kelangsungan hidup perusahaan dan bagaimana efeknya pada perusahaan. (Brigham dan Houston: 2011).

\section{Laba Akuntansi}

Accounting income atau "Laba akuntansi merupakan hasil penandingan antara pendapatan dan beban, atau selisih antara pendapatan atau beban yang berdasarkan pada prinsip realisasi atau aturan matching yang memadai". Laba akuntansi adalah laba yang timbul dari proses laporan keuangan, yaitu merupakan selisih dari hasil penjualan dikurangi dengan harga pokok dan biayabiaya operasi perusahaan (laba bersih). Laba akuntansi tertera dilaporan keuangan tahunan (annual reports) dan menunjukkan kinerja intern perusahaan yang menggambarkan kinerja perusahaan pada periode tertentu. (Yadianti; 2010)

\section{Dividen Kas}

Dividen kas yaitu perusahaan mendistribusikan kas kepada pemegang saham sebesar proporsi tertentu, mengacu pada rasio pembagian dividen dari laba bersih (Dwi dkk ;2016).

Menurut Ambarwati (2010;66) tipe dividen kas ada 4 macam, yaitu regular cash dividend, extra dividen, special dividend, dan liquidating dividend. Secara umum, perusahaan membayar dividen kas regular empat kali dalam satu tahun. Pembayaran kas diberikan secara langsung kepada pemegang saham dan pembayaran itu dibuat dalam bisnis regular. Terkadang perusahaan melakukan pembayaran dividen ekstra yang tidak pasti setiap tahunnya, bisa dilanjutkan tetapi bisa juga tidak dilanjutkan di masa datang. Pembayaran dividen spesial hampir sama, tetapi sering mengindikasi bahwa dividen ini diberikan sebagai sesuatu yang luar biasa dan tidak akan diulangi lagi, sesuatu yang benar-benar khusus. Dividen liquidasi (yang mungkin mengurangi pembayaran dalam modal). Faktor-faktor yang mempengaruhi dividen kas tergantung kepada jenis analisa yang digunakan. Apakah menggunakan analisa fundamental atau menggunakan analisa teknikal. Selain tergantung pada hal-hal yang mempengaruhi baik secara internal maupun eksternal. Faktor-faktor yang mempengaruhi dividen kas secara internal adalah faktor yang bersifat fundamental, yang meliputi tentang kemampuan manajemen dalam mengelola kegiatan operasional perusahaan dan kemampuan perusahaan dalam menghasilkan keuntungan. Sedangkan faktor-faktor yang mempengaruhi 
dividen kas secara eksternal adalah faktor yang bersifat teknis, meliputi faktor sosial, ekonomi dan politik yang berpengaruh baik secara langsung maupun tidak langsung (Widoyono dan Mita; 2011).

Kerangka konseptual dari penelitian ini, variabel independent yaitu laba akuntansi (X1) dan laba tunai (X2), serta variabel dependent yaitu dividen kas (Y).

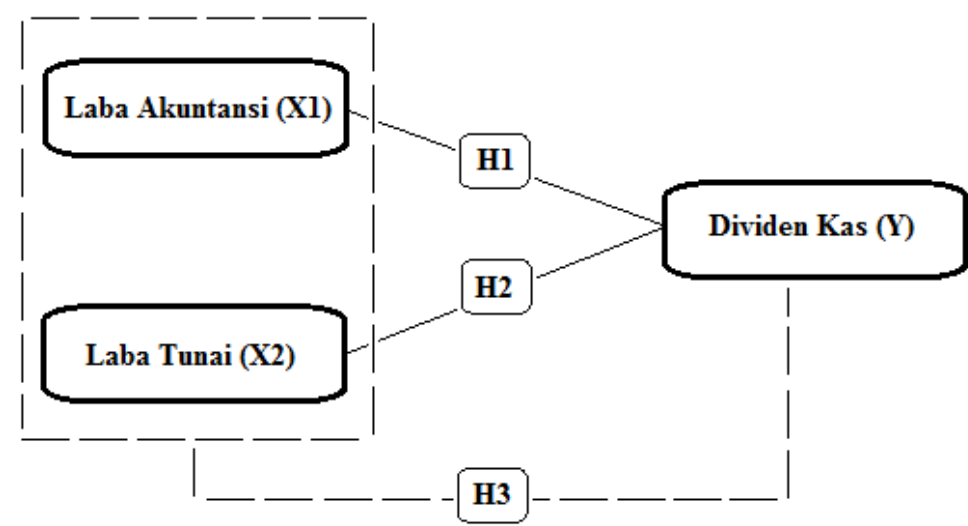

Gambar 2.1

Kerangka Konseptual

Dan untuk hipotesis pada penelitian ini adalah:

H1 : Laba akuntansi berpengaruh terhadap dividen kas.

$\mathrm{H} 2$ : Laba tunai berpengaruh terhadap dividen kas.

H3 : Laba akuntansi dan laba tunai secara bersama-sama berpengaruh terhadap dividen kas.

\section{METODE PENELITIAN}

Jenis penelitian ini adalah deskriptif kuantitatif dengan menggunakan data sekunder. Penelitian ini dilakukan pada perusahaan manufaktur sektor farmasi yang terdaftar di Bursa Efek Indonesia (BEI). Data yang dipergunakan yaitu laporan keuangan periode 2013-2017 yang diperoleh dengan mengakses website (www.idx.co.id dan www.idnfinancial.com) dan situs resmi masing-masing perusahaan. Adapun penelitian ini dilakukan untuk mengetahui seberapa besar pengaruh Laba Akuntansi dan Laba Tunai terhadap Dividen Kas pada perusahaan manufaktur sektor farmasi yang terdaftar di Bursa Efek Indonesia (BEI) tahun 2013-2017.

\section{Teknik Pengumpulan data}

Teknik pengumpulan data yang digunakan dalam penelitian ini adalah dengan studi pustaka, dimana peneliti mencari referensi dan landasan teori dalam buku, hasil penelitian terdahulu atau jurnal yang sesuai dengan apa yang sedang di teliti. Dan ditambahkan dengan metode dokumentasi, menggunakan data atau informasi dari subjek dan objek yang sudah ada. Dalam penelitian ini pengumpulan data di dapatkan dari laporan keuangan perusahaan farmasi yang terdaftar dan di 
publikasi di website www.idx.co.id dan website masing-masing perusahaan.

\section{Variabel dan Pengukuran}

Dalam peneliian ini, menggunakan Variable Independent dan Variable Dependent, yang diuraikan sebagai berikut :

Yang menjadi variabel independen dalam penelitian ini :

1. Laba akuntansi adalah perbedaan antara revenue yang direalisasi yang timbul dari transaksi pada periode tertentu dihadapkan dengan biaya-biaya yang dikeluarkan pada periode tersebut. Dapat disimpulkan laba akuntansi adalah laba yang diperoleh dari penjualan bersih dikurangi harga pokok penjualan dan biaya perusahaan. Laba akuntansi merupakan laba bersih yang dilaporkan dalam laporan keuangan. Laba akuntansi dapat dihitung menggunakan rumus yang dikembangkan (Syamsul Hadi ; 2006) :

Laba akuntansi $=$ Hasil Penjualan $-($ HPP + Biaya Operasi Perusahaan $)$

2. Cash income is strictly objective. It is based on cash inflows and outflows. Cash realization is the only trigeer for recognition of income. (Evans; 2003) Artinya laba tunai adalah laba akuntansi yang telah disesuaikan dengan transaksi non akuntansi, seperti beban penyusutan, beban amortisasi, penjualan kredit, beban gaji, beban pajak, dan beban bunga yang belum dibayar, serta pembelian kredit. Laba akuntansi dapat dihitung dengan rumus menurut Syamsul Hadi: 2006).

Laba Tunai=Laba Akuntansi + Beban Non Kas - Pendapatan Non Kas.

Dalam penelitian ini, yang menjadi variabel dependen adalah dividen kas . Dividen kas dalam penelitian ini merupakan laba dalam bentuk uang kas yang dibayarkan kepada pemegang saham berdasarkan RUPS ( Rapat Umum Pemegang Saham ). Menurut Kieso et al: 2010 , Dividen kas merupakan distribusi laba kepada para pemegang saham yang berbentuk uang kas. Dividen kas dapat menyebabkan penurunan terhadap laba yang dibagi dengan kas, karena dividen ini menggunakan uang kas dari perusahaan"

\section{Populasi dan Sampel}

Populasi yang digunakan dalam penelitian ini adalah perusahaan farmasi yang terdaftar dalam Bursa Efek Indonesia pada periode 2013-2017. Data tersebut berupa laporan keuangan tahunan yang didapat dari Pusat Referensi Pasar Modal Bursa Efek Indonesia. Pemilihan sampel dalam penelitian ini menggunakan teknik purposive sampling, yaitu teknik pengumpulan sampel dengan pertimbangan tertentu atau teknik pemilihan sampel dengan beberapa kriteria tertentu bertujuan untuk mendapatkan sampel yang representative sesuai dengan kriteria yang 
ditentukan. Karakteristik sampel yang diambil dalam penelitian ini, antara lain :

1. Perusahaan manufaktur sub-sektor farmasi yang terdaftar di Bursa Efek Indonesia (BEI) periode 2013-2017.

2. Perusahaan manufaktur sektor farmasi yang membagikan dividen kasnya selama periode 2013-2017 secara berturut-turut.

3. Perusahaan manufaktur sub-sektor Farmasi yang laporan keuangannya menggunakan mata uang rupiah selama periode 2013-2017.

4. Perusahaan yang memiliki informasi laporan keuangan yang lengkap sesuai dengan data yang diperlukan dalam mendukung penelitian.

\subsection{Teknik Analisis}

Analisis data ini bertujuan untuk mengetahui peran masing-masing variabel independen dalam mempengaruhi variabel dependen. Analisis data dalam penelitian ini menggunakan data panel (pooled data) yaitu gabungan dari data runtut waktu (time series) dan data silang (cross section). Kemudian Pengujian hipotesis dilakukan dengan model regresi data panel. Dan data penelitian tersebut akan di hitung menggunakan program software Eviews 9.

Menurut Basuki (2016), dalam metode estimasi model regresi dengan menggunakan data panel dapat dilakukan melalui tiga pendekatan, antara lain :

1. Common Effect Model merupakan pendekatan model data panel yang paling sederhana karena hanya mengombinasikan data time series dan data cross section. Pada model ini tidak diperhatikan dimensi waktu maupun individu, sehingga diasumsikan bahwa perilaku data perusahaan sama dalam berbagai kurun waktu. Metode ini bisa menggunakn pendekatan Ordinary Least Square $(O L S)$ atau teknik kuadarat terkecil untuk mengestimasi model data panel.

2. Fixed Effect Model model ini mengasumsikan bahwa perbedaan antar individu dapat diakomodasi dari perbedaan intersepnya. Untuk mengestimasi data panel Model Fixed Effect menggunakan tehnik variabel dummy untuk menangkap perbedaan intersep antar perusahaan. Namun demikian, slopenya sama antar perusahaan. Model estimasi ini sering juga disebut dengan teknik Least Squares Dummy Variable (LDSV).

3. Random Effect Model model ini akan mengestimasi data panel dimana variabel gangguan mungkin saling berhubungan antar waktu dan antar individu. Pada model random effect perbedaan intersep diakomodasi oleh error terms masingmasing perusahaan.

Untuk menentukan model data yang tepat, dilakukan beberapa uji diantaranya : Uji Chow Merupakan pengujian untuk menentukan Fixed Effect Model atau Common Effect Model yang paling tepat digunakan dalam mengestimasi data panel. Uji Hausman merupakan pengujian statistik untuk memilih apakah Fixed Effect Model atau Random Effect Model yang paling tepat digunakan. Uji Lagrange Multiplier merupakan pengujian statistik untuk mengetahui apakah Random Effect Model lebih baik dari pada Commont Effect Model.

Setelah model data di dapatkan maka dilakukan uji deskriptif, uji asumsi 
klasik yang terdiri dari uji normalitas, uji multikolinearitas, uji heterokedasitas dan uji autokorelasi. Kemudian dilanjutkan dengan analisis regresi linear berganda. Pada penelitian ini juga dilakukan uji Koefisien Determinasi (R2) dilakukan dengan tujuan untuk mengetahui presentase pengaruh variabel independen terhadap perubahan variabel dependen. Dan yang terakhir adalah pengujian hipotesis dengan menggunakan uji parsial dan uji simultan.

\section{ANALISIS DATA DAN DISKUSI HASIL}

Dalam penelitian kali ini, objek dalam penelitian ini adalah perusahaan farmasi yang telah terdaftar di Bursa Efek Indonesia tahun 2013 sampai tahun 2017.

\section{Sampel Penelitian}

Pada penelitian ini didapatkan sampel menggunakan kriteria yang dijelaskan dalam tabel dibawah ini :

Tabel 4. 1

Pemilihan Sampel Berdasarkan Karakteristik yang Ditetapkan

\begin{tabular}{|c|c|c|c|}
\hline No. & Kriteria & $\begin{array}{l}\text { Pelanggaran } \\
\text { Kriteria }\end{array}$ & $\begin{array}{l}\text { Jumlah } \\
\text { Data }\end{array}$ \\
\hline 1 & $\begin{array}{l}\text { Perusahaan manufaktur sektor farmasi yang terdaftar di } \\
\text { Bursa Efek Indonesia (BEI) periode 2013-2017. }\end{array}$ & - & 10 \\
\hline 2 & $\begin{array}{l}\text { Perusahaan manufaktur sektor farmasi yang membagikan } \\
\text { dividen kasnya selama periode 2013-2017 secara } \\
\text { berturut-turut. }\end{array}$ & 15 & 35 \\
\hline 3 & $\begin{array}{l}\text { Perusahaan manufaktur yang laporan keuangannya } \\
\text { menggunakan mata uang rupiah selama periode 2013- } \\
2017 \text {. }\end{array}$ & - & 50 \\
\hline 4 & $\begin{array}{l}\text { Perusahaan yang memiliki informasi lapoan keuangan } \\
\text { yang lengkap sesuai dengan data yang diperlukan dalam } \\
\text { mendukung penelitian. }\end{array}$ & 15 & 35 \\
\hline & Jumlah sampel penelitian & \multicolumn{2}{|c|}{7} \\
\hline & Tahun Penelitian & \multicolumn{2}{|c|}{5} \\
\hline & Total sampel penelitian & \multicolumn{2}{|c|}{35} \\
\hline
\end{tabular}

Dari tabel di atas, diketahui bahwa sampel yang digunakan sebanyak 7 perusahaan farmasi yang terdaftar di Bursa Efek Indonesia dengan periode laporan keuangan dari tahun 2013-2017, sehingga data yang digunakan ada sebanyak 35 laporan keuangan. Model data yang digunakan melalui Uji Chow Test atau Likelihood Ratio Test adalah sebuah pengujian untuk memilih antara model common effect dengan model fixed effect. Hasil Uji Chow disajikan dalam tabel di bawah ini : 


\section{Tabel 4. 2}

Hasil Uji Chow

Redundant Fixed Effects Tests

Equation: Untitled

Test cross-section fixed effects

\begin{tabular}{lrrr}
\hline \hline Effects Test & Statistic & d.f. & Prob. \\
\hline \hline & & & \\
Cross-section F & 4.494883 & $(6,26)$ & 0.0030 \\
Cross-section Chi-square & 24.906556 & 6 & 0.0004 \\
\hline \hline
\end{tabular}

Sumber: Lampiran ; Output EViews versi 9

Dari tabel 4.2 terlihat bahwa Prob. Cross-section F sebesar 0,0030>0,05, dapat disimpulkan bahwa antara model common effect dan fixed effect lebih tepat menggunakan model fixed effect.

Untuk hasil Uji Hausman adalah :

\section{Tabel 4. 3}

\section{Uji Hausman}

Correlated Random Effects - Hausman Test

Equation: Untitled

Test cross-section random effects

\begin{tabular}{|c|c|c|c|}
\hline Test Summary & $\begin{array}{l}\text { Chi-Sq. } \\
\text { Statistic }\end{array}$ & Chi-Sq. d.f. & Prob. \\
\hline Cross-section random & 0.460069 & 2 & 0.7945 \\
\hline
\end{tabular}

Sumber: Lampiran ; Output EViews versi 9

Dari tabel 4.3 terlihat bahwa Prob. Cross-section sebesar 0,7945>0,05, dapat disimpulkan bahwa antara model fixed effect dan random effect lebih tepat menggunakan model random effect.

Selanjutnya dilakukan Uji Lagrange Multiplier dan didapatkan hasil : 


\section{Tabel 4.4}

\section{Uji Lagrange Multiplier}

Lagrange Multiplier Tests for Random Effects

Null hypotheses: No effects

Alternative hypotheses: Two-sided (Breusch-Pagan) and one-sided (all others) alternatives

\begin{tabular}{|c|c|c|c|}
\hline & Cross-section & $\begin{array}{l}\text { est Hypothes } \\
\text { Time }\end{array}$ & Both \\
\hline Breusch-Pagan & $\begin{array}{l}9.682756 \\
(0.0019)\end{array}$ & $\begin{array}{l}0.122178 \\
(0.7267)\end{array}$ & $\begin{array}{l}9.804934 \\
(0.0017)\end{array}$ \\
\hline Honda & $\begin{array}{l}3.111713 \\
(0.0009)\end{array}$ & $\begin{array}{c}-0.349539 \\
--\end{array}$ & $\begin{array}{l}1.953152 \\
(0.0254)\end{array}$ \\
\hline King-Wu & $\begin{array}{l}3.111713 \\
(0.0009)\end{array}$ & $\begin{array}{c}-0.349539 \\
--\end{array}$ & $\begin{array}{l}1.697268 \\
(0.0448)\end{array}$ \\
\hline Standardized Honda & $\begin{array}{l}4.600100 \\
(0.0000)\end{array}$ & $\begin{array}{c}-0.137922 \\
--\end{array}$ & $\begin{array}{c}-0.070545 \\
--\end{array}$ \\
\hline Standardized King-Wu & $\begin{array}{l}4.600100 \\
(0.0000)\end{array}$ & $\begin{array}{c}-0.137922 \\
--\end{array}$ & $\begin{array}{c}-0.371403 \\
--\end{array}$ \\
\hline Gourierioux, et al.* & -- & -- & $\begin{array}{l}9.682756 \\
(<0.01)\end{array}$ \\
\hline
\end{tabular}

Sumber: Lampiran ; Output EV

Dari tabel 4.4 terlihat bahwa Prob. Breush-Pagan sebesar 0,0019<0,05. Berdasarkan Uji Lagrange Multiplier dapat disimpulkan bahwa antara model common effect dan random effect lebih tepat menggunakan model random effect.

Berikut hasil uji statistik deskriptif pada penelitian ini:

Tabel 4.5

Hasil Uij Statik Deskriptif

\begin{tabular}{|l|l|l|l|}
\hline & \multicolumn{1}{|c|}{ DIVIDEN KAS } & \multicolumn{1}{c|}{ LABA AKUNTANSI } & \multicolumn{1}{c|}{ LABA TUNAI } \\
\hline Mean & 273496422310.0857 & 561882744939.4857 & 487897112816.9429 \\
\hline Median & 163840000000 & 265549762082 & 174350046220 \\
\hline Maximum & 1047790983485 & 2453251410604 & 2172012422539 \\
\hline Minimum & 24640000000 & 81597761000 & 65568837000 \\
\hline Std. Dev. & 289173767439.8372 & 696933304364.703 & 628966041698.5911 \\
\hline Skewness & 1.515029335787854 & 1.87120188154537 & 1.893598253380686 \\
\hline Kurtosis & 4.092487708781352 & 4.928802096284839 & 4.935945687035315 \\
\hline & & & \\
\hline Jarque-Bera & 15.12989471441798 & 25.85021753508325 & 26.38233366413192 \\
\hline Probability & 0.0005183046520533808 & $2.436108259673553 \mathrm{e}-06$ & $1.867020278267795 \mathrm{e}-06$ \\
\hline & & & \\
\hline Sum & 9572374780853 & 19665896072882 & 17076398948593 \\
\hline Sum Sq. Dev. & $2.843129904361867 \mathrm{e}+24$ & $1.651434504491193 \mathrm{e}+25$ & $1.345034157473979 \mathrm{e}+25$ \\
\hline & & & 35 \\
\hline Observations & 35 & 35 & 35 \\
\hline Sumber: Lampiran & Output EViews vers & & \\
\hline
\end{tabular}

Sumber: Lampiran ; Output EViews versi 9 
Dari tabel 4.5 deskriptif statistik di atas, diketahui nilai dividen kas minimum sebesar 0,26\% atau sebesar Rp 24.640.000.000,00 dimiliki oleh PT Darya Faria Labortoria Tbk pada tahun 2014. Sedangkan nilai maksimal dividen kas yakni 11,04\% sebesar Rp 1.047.790.983.485 PT Kalbe Farma Tbk di tahun 2017 dengan nilai rata-rata sebesar $20,07 \%$.

Pada variabel laba akuntansi tingkat minimum yang diperoleh PT Darya Faria Labortoria Tbk pada tahun 2014 sebesar Rp 81.597.761.000,00. Sementara itu laba akuntansi tingkat maksimum dimiliki oleh PT Kalbe Farma Tbk sebesar Rp 2.453.251.410.604,00 pada tahun 2017. Tingkat rata-rata laba akuntansi $\mathrm{Rp}$ 561.882.744.900,00.

Pada variabel laba tunai, perusahaan yang memiliki laba tunai tingkat minimum adalah PT Darya Faria Labortoria Tbk sebesar Rp 65.568.837.000,00 pada tahun 2014. Sedangkan tingkat maksimum laba tunai dimiliki oleh PT Kalbe Farma Tbk pada tahun 2017 sebesar Rp 2.172.012.422.539,00 dan tingkat rata rata perusahaan diperoleh sebesar Rp 487.897.112.800,00

Uji normalitas dalam penelitian ini dilakukan dengan uji statistic Jarque-Bera test. Berikut ini hasil dari Uji Normalitas penelitian ini:

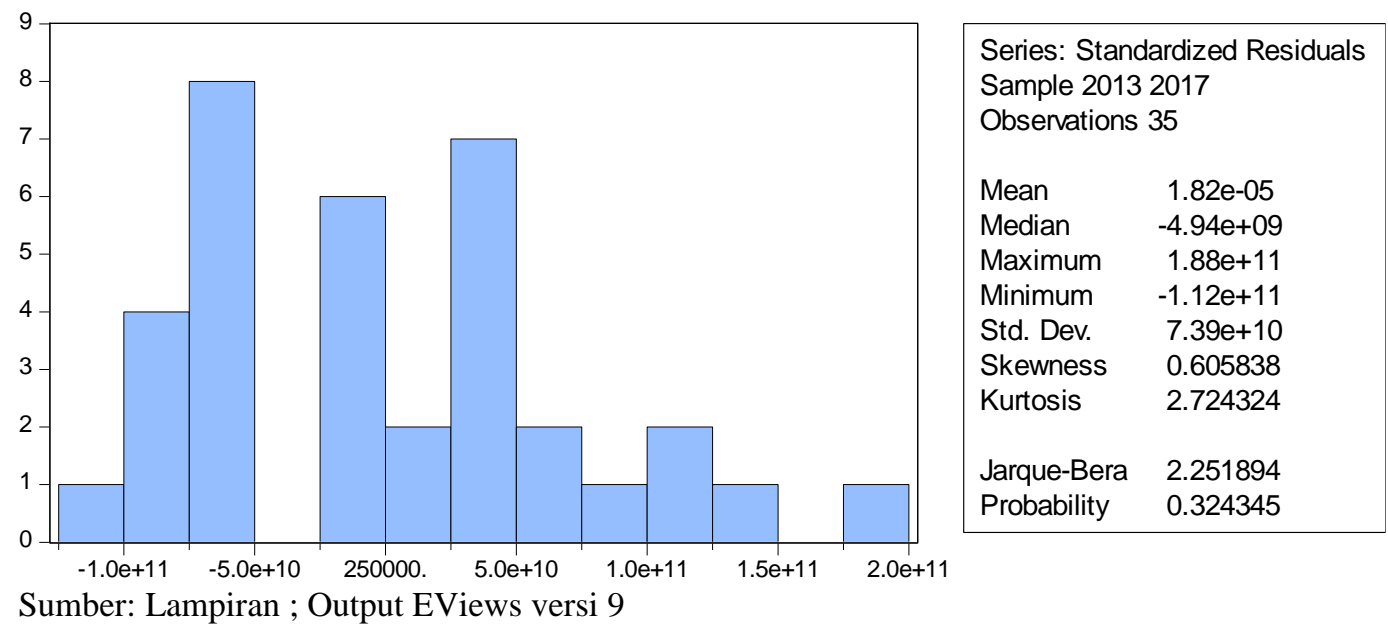

Gambar 4. 1

Uji Normalitas

Dari tabel di atas menunjukkan nilai probabilitas Jarque-bera sebesar 0,324345 .Nilai probabilitas Jarque-bera lebih besar dari taraf signifikansi (0.324345>0.05), sehingga dapat disimpulkan data terdistribusi normal.

Uji autokorelasi dilakukan untuk mengetahui ada tidaknya korelasi antara faktor penggangu antar variabel (non autokolelation). 
Tabel 4. 6

Uji Autokorelasi

\begin{tabular}{|c|c|c|c|c|}
\hline Variable & Coefficient & Std. Error & t-Statistic & Prob. \\
\hline $\mathrm{C}$ & $-1.97 \mathrm{E}+12$ & $1.44 \mathrm{E}+12$ & -1.362445 & 0.1826 \\
\hline Laba Akuntansi & 0.295107 & 0.079202 & 3.726005 & 0.0008 \\
\hline Laba Tunai & $7.87 \mathrm{E}+10$ & $5.62 \mathrm{E}+10$ & 1.398811 & 0.1715 \\
\hline \multicolumn{5}{|c|}{ Effects Specification } \\
\hline & & & S.D. & Rho \\
\hline Cross-section random & & & $6.12 \mathrm{E}+10$ & 0.5270 \\
\hline Idiosyncratic random & & & $5.80 \mathrm{E}+10$ & 0.4730 \\
\hline \multicolumn{5}{|c|}{ Weighted Statistics } \\
\hline R-squared & 0.805221 & \multicolumn{2}{|c|}{ Mean dependent var } & $1.07 \mathrm{E}+11$ \\
\hline Adjusted R-squared & 0.793047 & \multicolumn{2}{|c|}{ S.D. dependent var } & $1.24 \mathrm{E}+11$ \\
\hline S.E. of regression & $5.66 \mathrm{E}+10$ & \multicolumn{2}{|c|}{ Sum squared resid } & $1.02 \mathrm{E}+23$ \\
\hline F-statistic & 66.14421 & \multicolumn{2}{|c|}{ Durbin-Watson stat } & 2.367743 \\
\hline $\operatorname{Prob}(F-$-statistic $)$ & 0.000000 & & & \\
\hline
\end{tabular}

Didapatkan nilai DW sebesar 2,367743. Dan dimana nilai batas atas (dU) sebesar 1,584, nilai batas bawah sebesar (dL) 1,343, dan nilai 4-dU dan 4-dL masing-masing sebesar 2,416 dan 2,657. Maka dapat disimpulkan 1,584 < $2,367743<2,416$ dan tidak terjadi autokorelasi.

Tabel 4.7 Uji Multikolinieritas

\begin{tabular}{|c|c|c|}
\hline & LABA AKUNTANSI & LABA TUNAI \\
\hline \hline LABA AKUNTANSI & 1.000000 & 0.506598 \\
LABA TUNAI & 0.506598 & 1.000000 \\
\hline
\end{tabular}

Dari tabel di atas, diperoleh hasil berupa nilai korelasi masing-masing variabel bebas $<0.85$ artinya tidak terjadi masalah multikolinieritas.

Dalam uji Heterokedastisitas kita juga dapat melihat nilai Bruesch-Pagan LM, dengan nilai signifikansi 0,05 . 
Tabel 4.8

Uji Heterokedastisitas

Heteroskedasticity Test: White

\begin{tabular}{llll}
\hline \hline F-statistic & 1.304690 & Prob. F(5,29) & 0.2893 \\
Obs*R-squared & 6.427326 & Prob. Chi-Square(5) & 0.2668 \\
Scaled explained SS & 4.971608 & Prob. Chi-Square(5) & 0.4194 \\
\hline \hline
\end{tabular}

Residual Cross-Section Dependence Test

Null hypothesis: No cross-section dependence (correlation) in residuals

Equation: Untitled

Periods included: 5

Cross-sections included: 7

Total panel observations: 35

Note: non-zero cross-section means detected in data

Cross-section means were removed during computation of correlations

\begin{tabular}{lrrr}
\multicolumn{1}{c}{ Test } & Statistic & d.f. & Prob. \\
\hline \hline Breusch-Pagan LM & 22.03253145834661 & 21 & 0.3976372852937948 \\
Pesaran scaled LM & -0.9208003867705172 & 0.3571546530320774 \\
Pesaran CD & 1.752881087345254 & & 0.07962242060460688 \\
\hline \hline
\end{tabular}

Berdasarkan tabel di atas, diperoleh hasil berupa nilai probabilitas chi squares sebesar 0.2668. Nilai probabilitas chi squares lebih besar dari taraf signifikansi $(0.2668>0.05)$, selain itu dapat kita lihat nilai probabilitas Breusch-Pagan LM sebesar $0.3976>0.05$, artinya tidak terjadi heterokedastisitas.

Uji hipotesis pada penelitian ini dilakukan dengan Adjusted $\mathrm{R}^{2}$, uji parsial, dan uji signifikan simultan. Uji hipotesis ini dilakukan menggunakan program Eviews versi 9 dan berikut ini hasil dari olah data sebagaimana berikut ini: 
Tabel 4. 9

Hasil Uji Hipotesis dengan Metode Random Effects

\begin{tabular}{ccccc}
\hline \hline Variable & Coefficient & Std. Error & t-Statistic & Prob. \\
C & & & & \\
Laba Akuntansi & $-1.97 \mathrm{E}+12$ & $1.44 \mathrm{E}+12$ & -1.362445 & 0.1826 \\
Laba Tunai & 0.295107 & 0.079202 & 3.726005 & 0.0008 \\
\hline \hline
\end{tabular}

Effects Specification

S.D. Rho

\begin{tabular}{lll}
\hline \hline & & \\
Cross-section random & $6.12 \mathrm{E}+10$ & 0.5270 \\
Idiosyncratic random & $5.80 \mathrm{E}+10$ & 0.4730 \\
\hline \hline
\end{tabular}

Weighted Statistics

\begin{tabular}{lcll}
\hline \hline & & & \\
R-squared & 0.805221 & Mean dependent var & $1.07 \mathrm{E}+11$ \\
Adjusted R-squared & 0.793047 & S.D. dependent var & $1.24 \mathrm{E}+11$ \\
S.E. of regression & $5.66 \mathrm{E}+10$ & Sum squared resid & $1.02 \mathrm{E}+23$ \\
F-statistic & 66.14421 & Durbin-Watson stat & 2.367743 \\
Prob(F-statistic) & 0.000000 & & \\
\hline \hline & & & \\
& & & \\
& & & \\
& 0.936647 & Mean dependent var & \\
R-squared & $1.80 \mathrm{E}+23$ & Durbin-Watson stat & \\
Sum squared resid & &
\end{tabular}

Berdasarkan tabel 4.9 maka diperoleh persamaan linear sebagai berikut:

$\mathrm{Y}=-1.97+0,295 \mathrm{X}_{1}+7,87 \mathrm{X}_{2}+\mathrm{e}$

Dari persamaan regresi tersebut dapat diartikan sebagai berikut:

1. Nilai konstanta sebesar -1.97 artinya nilai dividen kas sebesar -1.97 ketika laba akuntansi dan laba tunai bernilai nol. 
2. Nilai koefisien regresi laba akuntansi sebesar 0,295 artinya setiap kenaikan satu satuan laba akuntansi maka dividen kas akan bertambah sebesar 0,295.

3. Nilai koefisien regresi laba tunai sebesar 7,87 artinya setiap kenaikan satu satuan laba tunai maka dividen kas akan bertambah sebesar 7,87.

4. Pada tabel di atas menunjukan bahwa nilai Adjusted R-squared sebesar 0,793047, artinya bahwa variasi perubahan naik turunnya Dividen Kas dapat dijelaskan oleh Laba Akuntansi dan Laba Tunai sebesar 79,3\%, sementara sisanya yaitu sebesar $20,7 \%$ dijelaskan oleh variabel lainnya yang tidak diteliti dalam penelitian ini

\subsection{Diskusi Hasil Penelitian}

Hasil Penelitian untuk menjawab dari hipotesis yang telah diajukan pada penelitian ini, dapat dijelaskan sebagai berikut :

1. Pengaruh Laba Akuntansi Terhadap Dividen Kas

Nilai $t$-statistic dari Laba Akuntansi sebesar 3,726005, sementara t tabel 1 sebesar 2,037. Dengan demikian $t$-statistic laba akuntansi 3,726005 > 2,037 dan nilai Prob. $0,0008<0.05$. Maka dapat disimpulkan bahwa variabel laba akuntansi dalam penelitian ini memiliki pengaruh terhadap dividen kas.

2. Pengaruh Laba Tunai Terhadap Dividen Kas

Nilai $t$-statistic dari Laba Tunai sebesar 1,398811, sementara t tabel sebesar 2,037. Dengan demikian $t$-statistic laba akuntansi 1,398811 <2,037 dan nilai Prob. 0,1715> 0,05. Maka dapat disimpulkan bahwa variabel laba tunai dalam penelitian ini tidak berpengaruh terhadap dividen kas.

3. Pengaruh Laba Akuntansi dan Laba Tunai Berpengaruh Secara Simultan Terhadap Dividen Kas

Pada tabel di atas menunjukan bahwa nilai $F$-statistic sebesar 40,33767, sementara F tabel sebesar 3,23. Dengan demikian $F$-statistic 66,14421 >3,23 dan nilai Prob (F-statisti) $0,0000<0.05$, maka dapat disimpulkan bahwa variabel independen dalam penelitian yang terdiri dari laba akuntansi dan laba tunai secara bersama-sama memiliki pengaruh terhadap dividen kas.

\section{KESIMPULAN}

Berdasarkan hasil analisa dan uji hipotesis yang telah dilakukan dalam penelitian ini, maka dapat disimpulkan sebagai berikut :

1. Laba akuntansi berpengaruh terhadap dividen kas pada perusahaan Farmasi yang terdaftar di BEI tahun 2013-2017. Hasil ini menunjukan bahwa sebagian besar perusahaan farmasi yang terdaftar pada BEI periode tahun 2013-2017 cenderung membagikan dividen kas kepada pemegang saham berdasarkan laba akuntansi. Ini sesuai dengan penelitian yang dilakukan oleh Rosna Khairani Harahap (2007) dengan judul penelitian Hubungan Antara Laba 
Akuntansi dan Laba tunai dengan Dividen Kas pada Perusahaan Manufaktur yang Terdaftar di BEI, yaitu sebagian perusahaan membagikan dividen kas berdasarkan perolehan laba akuntansi.

2. Laba tunai tidak berpengaruh terhadap dividen kas pada perusahaan Farmasi yang terdaftar di BEI tahun 2013-2017.

Hal ini dapat berarti laba akuntansi lebih mempengaruhi tingkat pembagian dividen kas dibandingkan dengan ketersedian laba tunai yang diperoleh dari aktivitas operasi. Perusahaan masih mampu membagikan dividen kas, meskipun nilai laba tunai mengalami penurunan secara keseluruhan. Hal ini terjadi karena dalam akuntansi terdapat metode pencatatan akrual seperti pengakuan pendapatan, yang artinya pendapatan dapat dicatat dan diakui walaupun secara kas belum dapat diterima. Karena itu pendapatan sudah dapat diakui dan dapat digunakan sebagai dasar pengambilan keputusan dan ketersediaan kas atau laba tunai yang dimiliki tidak mempengaruhi pembagian dividen kas. Hal ini didukung dengan penelitian yang sebelumnya dilakukan oleh Hani Sri Mulyani (2015) dengan judul penelitian Pengaruh Laba Tunai dan Laba Akuntansi terhadap Dividen Kas.

3. Laba akuntansi dan laba tunai secara simultan (bersama-sama) berpengaruh terhadap dividen kas pada perusahaan Farmasi yang terdaftar di BEI pada tahun 2013-2017. Dari hasil penelitian ini menujukan bahwa laba akuntansi dan laba tunai secara bersama-sama akan mempengaruhi dalam pembagian dividen kas kepada para investor. Sehingga para investor dapat menjadikan laba akuntansi dan laba tunai sebagai acuan atau bahan pertimbangan dalam pengambilan keputusan untuk membeli, menjual kembali atau menahan saham berdasarkan harapan atas dividen kas yang dibagikan.

\section{DAFTAR PUSTAKA}

Ambarwati, E,R, Diah, W. (2010). Asuhan Kebidanan Nifas. Yogyakarta: Nuha Medika

Arthur J. Keown, (2008). Manajemen Keuangan, Edisi 10, Jakarta: PT Macanan Jaya Cemerlang

Basuki, Agus Tri and Prawoto, Nano. (2016). Analisis Regresi Dalam Penelitian Ekonomi \& Bisnis : Dilengkapi Aplikasi SPSS \& EVIEWS. Depok : PT Rajagrafindo Persada

Brigham, Eugene F dan Joel F. Houston. (2011). Dasar - Dasar Manajemen Keuangan. Edisi 11. Erlangga. Jakarta.

Bustanul, Arifin. (2012). Perbedaan Kecenderungan Pengungkapan Corporate Social Responsibility Pengujian Terhadap Manejemen Laba Akrual dan Manajemen Laba Real. E-Jurnal Ekonomi UNTIRTA.

Harahap, Rosna Khairani. (2007). Hubungan Antara Laba Akutansi dan Laba Tunai Dengan Dividen Kas pada Perushaan Manufaktur yang Terdaftar di BEJ. Jurnal Akuntansi, Volume 7, Nomor 1, Januari, hal 51-72 
Kieso, Donald E., et al. (2010). Akuntansi Intermediate. Jakarta: Erlangga.

Mulyani, Hani Sri, (2015). Pengaruh Laba Tunai dan Laba Akuntansi terhadap Dividen Kas: Jurnal Ilmiah Manajemen \& Akuntansi. Volume 2, Nomor 2, Juli-Desember. Universitas Majalengka, hal 145-158

Subramanyam, KR dan John, J. Wild, (2010). Analisis Laporan Keuangan, Buku Satu, Edisi Sepuluh, Salemba Empat, Jakarta.

Sugiyono. (2016). Metode Penelitian Kuantitatif, Kualitatif dan R\&D. Bandung: PT Alfabet.

Syamsul, Hadi, (2006). Prediksi Laba Dengan Menggunakan Informasi Arus Kas dan Manajemen Laba. Sinergi. Kajian Bisnis dan Manajemen. Edisi Khusus of Finance. Hal 99-109.

Wahyudi, Henri Dwi, dkk. (2016). Pengaruh Ukuran Perusahaan, Profitabilitas, Kebijakan Deviden, Dan Keputusan Investasi Terhadap Nilai Perusahaan (Studi Penggunaan Indeks Lq-45 Periode 2010 -2014). Volume 1, Nomor 2, Desember 2016: 156-164.

Widoyono, Mita Kusnendar Putri, (2011), Analisa Dampak Faktor-Faktor Fundamental Perusahaan Terhadap Dividen Kas (Studi Kasus Di Perusahaan Manufaktur Yang Terdaftar Di Bursa Efek Indonesia), Jurnal Manajemen dan Bisnis, Vol 15, No 2.

Winwin, Yadianti. (2010). Teori Akuntansi: Suatu Pengantar : PT Kencana, Jakarta. www.idx.co.id

www.idnfinancials.com 